\title{
Tumors of the Foot and Ankle: A Single-institution Experience
}

\author{
Cristina P. Azevedo, MD ${ }^{1}$, José M. Casanova, MD, $\mathrm{PhD}^{2}$, Marta G. Guerra, MD ${ }^{2}$, António L. Santos, MD ${ }^{2}$, \\ Maria I. Portela, MD ${ }^{1}$, Paulo F. Tavares, $\mathrm{MD}^{2}$ \\ ${ }^{1}$ Department of Medical Oncology, Portuguese Oncology Institute of Coimbra, Coimbra, Portugal \\ ${ }^{2}$ Bone and Soft Tissue Tumor Unit, Coimbra University Hospital. Coimbra, Portugal
}

\section{A R T I C L E I N F O}

Level of Clinical Evidence: 4

Keywords:

bone

giant cell tumor

neoplasm

sarcoma

soft tissue

surgery

\begin{abstract}
A B S T R A C T
Tumors of the foot and ankle are rare, and the particular clinicopathologic features, therapeutic approach, and outcomes in this setting are not well established. From January 2000 to December 2010, 72 patients with primary musculoskeletal tumors of the foot and ankle, both benign and malignant, were treated at a single institution. Of the 72 patients, 56\% were female. The median age was 52 years. Of the 72 tumors, 62 (86.11\%) were located in the foot and 10 were located in the ankle; 63 (87.5\%) were soft tissue tumors and $9(12.5 \%)$ were bone tumors. Overall, 56 (78\%) were benign tumors and $16(22 \%)$ were malignant tumors. The most frequent soft tissue and bone diagnosis was giant cell tumor. The median follow-up period was 49 months. The vast majority of the tumors were located in the foot. Benign tumors were dominant, outnumbering malignant tumors by more than 3 to 1 . The diversity of the histologic benign types was evident, with giant cell tumor, angiomyoma, and lipoma the most frequent. Regarding the malignant tumors, a clear male predominance was present, the median age was 45 years, and the most frequent tumor was synoviosarcoma. The 9-year overall and disease-free survival rate was $65 \%$ and $40 \%$, respectively.
\end{abstract}

(c) 2013 by the American College of Foot and Ankle Surgeons. All rights reserved.
Tumors arising in the foot and ankle are relatively rare (1-8). Fewer than $2 \%$ of all sarcomas and fewer than $10 \%$ of soft tissue sarcomas arise in this location (9). Owing to the rarity of these tumors, the particular clinicopathologic features, therapeutic approach, and outcomes in this setting are not well established. Also, in many cases, an inadequate or late diagnosis of lesions arising in the foot and ankle has been correlated with greater rates of recurrence. Another important aspect is that complete surgical resection of malignant tumors of the foot and ankle is particularly difficult, because of the anatomic complexity of this functional unit.

The objective of the present study was to present the clinical outcomes of a series of 72 cases of tumors located in the foot and ankle, treated at a musculoskeletal oncology referral center, during an approximate 10 -year period.

\section{Patients and Methods}

A review was conducted using a collection of clinical records of all patients with histologically confirmed primary musculoskeletal tumors of the foot and ankle, benign and malignant, treated from January 2000 to September 2010, at a musculoskeletal

Financial Disclosure: None reported.

Conflict of Interest: None reported.

Address correspondence to: Cristina P. Azevedo, MD, Department of Medical Oncology, Portuguese Oncology Institute of Coimbra, Avenida Bissaya Barreto No. 98, Coimbra 3000-075, Portugal.

E-mail address: cristina.azv@gmail.com (C.P. Azevedo). tumor referral center. The patients were identified by searching through the informatic database of the pathology department. The present study did not include patients with pseudotumoral lesions, tumors treated with thermal ablation, or patients with metastatic lesions located in the foot and ankle. Patients were excluded if their clinical records were incomplete. The study was performed with the approval of the institutional review board of our institution.

A total of 72 cases were identified, and data were obtained on age, gender, anatomic location, histologic diagnosis, stage, treatment modality, surgery type, surgical margins, chemotherapy regimen, radiation dose, recurrence site, therapy for recurrence, treatment complications, treatment response, and interval to death or last follow-up visit. The bone tumors were staged according to the Enneking/ Musculoskeletal Tumor Society staging system, and the soft tissue bone tumors were staged using the American Joint Committee on Cancer staging system $(10,11)$. The functional outcome was not evaluated in the present study. Overall survival was defined as the interval in months from the diagnosis to the date of the last follow-up visit or death. Disease-free survival was defined as the interval in months with no evidence of disease, after curative treatment of the initial neoplastic disease.

\section{Statistical Analysis}

Overall survival and disease-free survival curves were constructed according to the Kaplan-Meier method and compared using the log-rank test. The differences were considered significant if $p<.05$. The software used for the statistical analysis was SPSS, version 19.0 (SPSS, Chicago, IL).

\section{Results}

A total of 72 patients with benign and malignant musculoskeletal tumors of the foot and ankle were diagnosed and treated, during the 
Table 1

Characteristics, treatment, and outcomes of benign tumors of foot and ankle $(n=56$ patients)

\begin{tabular}{|c|c|}
\hline Parameter & Value \\
\hline \multicolumn{2}{|l|}{ Age (y) } \\
\hline Median & 54 \\
\hline Range & $17-76$ \\
\hline \multicolumn{2}{|l|}{ Gender } \\
\hline Male & $22(39 \%)$ \\
\hline Female & $34(61 \%)$ \\
\hline \multicolumn{2}{|l|}{ Location } \\
\hline Foot & $48(86 \%)$ \\
\hline Forefoot & 23 \\
\hline Midfoot & 25 \\
\hline Hindfoot & 0 \\
\hline Ankle & $8(14 \%)$ \\
\hline \multicolumn{2}{|l|}{ Histologic type } \\
\hline Soft tissue & $49(88 \%)$ \\
\hline Bone tumors & 7 (12\%) \\
\hline Giant cell tumor & $11(19.8 \%)$ \\
\hline Angiomyoma & $7(12.5 \%)$ \\
\hline Lipoma & $7(12.5 \%)$ \\
\hline Schwannoma & $5(8.9 \%)$ \\
\hline Dermatofibroma & $4(7.1 \%)$ \\
\hline Angioleiomyoma & $4(7.1 \%)$ \\
\hline Osteocondroma & $3(5.3 \%)$ \\
\hline Fibroma & $3(5.3 \%)$ \\
\hline Fibrocondroma & $2(3.6 \%)$ \\
\hline Desmoid tumor & $2(3.6 \%)$ \\
\hline Leiomyoma & $2(3.6 \%)$ \\
\hline Hemangioma & $2(3.6 \%)$ \\
\hline Other & $4(7.1 \%)$ \\
\hline \multicolumn{2}{|l|}{ Treatment } \\
\hline Surgery & $56(100 \%)$ \\
\hline Resection & $53(95 \%)$ \\
\hline Amputation & $3(5 \%)$ \\
\hline \multicolumn{2}{|l|}{ Outcome } \\
\hline Continuously disease free & $54(96 \%)$ \\
\hline Local recurrence & $2(4 \%)$ \\
\hline Average disease-free interval (mo) & 52 \\
\hline
\end{tabular}

Data presented as $\mathrm{n}(\%)$, unless otherwise noted.

past 10 years, at the Bone and Soft Tissue Tumor Unit of Coimbra University Hospital (Coimbra, Portugal). Of the 72 patients, 40 (56\%) were female and 32 (44\%) were male. The median patient age was 52 (range 15 to 76 ) years. Our sample included 56 benign tumors (78\%) and 16 malignant tumors (22\%). Of the 72 tumors, $63(88 \%)$ were soft tissue tumors and $9(12 \%)$ were bone tumors; 62 (86\%) were located in the foot and $10(14 \%)$ in the ankle. The follow-up period ranged from 4 to 119 (median 49) months.

\section{Benign Tumors}

Of the 56 patients with benign tumors, 34 (61\%) were female and $22(39 \%)$ were male. The median age of the patients was 54 years, with a minimum age of 17 and a maximum age of 76 . The follow-up period ranged from 9 to 119 (median 56) months. Of the 56 benign tumors, $48(86 \%)$ were located in the foot and $8(14 \%)$ in the ankle. According to the regions of the foot, 23 tumors were located in the forefoot and 25 in the midfoot. No benign tumors were located in the hindfoot. There were 49 (88\%) soft tissue tumors and 7 (12\%) bone tumors. The most frequent histologic diagnoses were giant cell tumor (GCT) in 11 (19.8\%), angiomyoma in 7 (12.5\%), lipoma in 7 (12.5\%), and schwannoma in $5(8.9 \%)$. All patients underwent surgery. The surgery type was resection in 53 cases (95\%) and amputation in 3 (5\%). Two cases of soft tissue tumors of the foot had initially been treated with resection at another institution had local recurrence. One was a desmoid tumor and one was an angiolipoma. The average disease-free interval was 52 months. Both patients with local recurrence underwent resection; however, the patient with the desmoid tumor also underwent
Table 2

Characteristics of malignant tumors of the foot and ankle $(n=16$ tumors in 16 patients

\begin{tabular}{|c|c|}
\hline Parameter & Value \\
\hline \multicolumn{2}{|l|}{ Age (y) } \\
\hline Median & 45 \\
\hline Range & $15-75$ \\
\hline \multicolumn{2}{|l|}{ Gender } \\
\hline Male & $10(62 \%)$ \\
\hline Female & $6(38 \%)$ \\
\hline \multicolumn{2}{|l|}{ Location } \\
\hline Foot & $14(88 \%)$ \\
\hline Forefoot & 5 \\
\hline Midfoot & 8 \\
\hline Hindfoot & 1 \\
\hline Ankle & $2(12 \%)$ \\
\hline \multicolumn{2}{|l|}{ Histologic type } \\
\hline Soft tissue tumors & $14(88 \%)$ \\
\hline Synoviosarcoma & 5 \\
\hline Malignant fibrous histiocytoma & 2 \\
\hline Liposarcoma & 2 \\
\hline Fibrosarcoma & 2 \\
\hline Clear cell sarcoma & 1 \\
\hline Leiomyosarcoma & 1 \\
\hline Chondrosarcoma & 1 \\
\hline Bone tumors & $2(12 \%)$ \\
\hline Osteosarcoma & 1 \\
\hline Fusocellular sarcoma & 1 \\
\hline \multicolumn{2}{|l|}{ Stage } \\
\hline \multicolumn{2}{|l|}{ Soft tissue tumors } \\
\hline IA & 2 \\
\hline IB & 3 \\
\hline IIA & 3 \\
\hline IIB & 1 \\
\hline III & 4 \\
\hline IV & 1 \\
\hline \multicolumn{2}{|l|}{ Bone tumors } \\
\hline IIA & 1 \\
\hline III & 1 \\
\hline
\end{tabular}

Data presented as $\mathrm{n}(\%)$, unless otherwise noted.

complementary radiotherapy after surgery. Four months after treatment of the recurrence, the desmoid tumor recurred again, and the patient underwent amputation. None of the patients had evidence of disease at the last follow-up. The characteristics, treatment, and outcomes of the patients with benign tumors are summarized in Table 1.

\section{Malignant Tumors}

Of the 16 patients with malignant tumors, 10 (62\%) were male and $6(38 \%)$ were female. The median patient age was 45 (range 15 to 75 ) years. The follow-up period ranged from 3 to 110 (median 27) months. Fourteen tumors $(88 \%)$ were located in the foot and $2(12 \%)$ in the ankle. According to the regions of the foot, 5 tumors were located in the forefoot, 8 in the midfoot, and 1 in the hindfoot. Of the 16 malignant tumors, 14 (88\%) were soft tissue tumors and $2(12 \%)$ were bone tumors. The most frequent histologic diagnosis was synoviosarcoma in 5 cases (31\%). Two patients had metastases at diagnosis. The characteristics of the patients with malignant tumors are summarized in Table 2.

\section{Treatment}

All patients underwent surgery. A significant number of patients underwent amputation (44\%). The surgical margins were wide or radical in $56 \%$ of the cases; $62 \%$ of the patients received chemotherapy. Chemotherapy, used in the neoadjuvant, adjuvant, or palliative setting, consisted of multiagent regimens containing, in most cases, cysplatin, doxorubicin, methotrexate, etoposide, 
Table 3

Treatment of malignant tumors of foot and ankle ( $\mathrm{n}=16$ tumors in 16 patients)

\begin{tabular}{lc}
\hline Parameter & $\mathrm{n}(\%)$ \\
\hline Treatment & $16(100 \%)$ \\
$\quad$ Surgery & $10(62 \%)$ \\
Chemotherapy & $4(26 \%)$ \\
$\quad$ Radiotherapy & \\
Surgery (primary tumor) & $9(56 \%)$ \\
$\quad$ Resection & $7(44 \%)$ \\
Amputation & $7(44 \%)$ \\
Surgical margins & $9(56 \%)$ \\
$\quad$ Marginal & \\
Wide/radical & \\
\hline
\end{tabular}

paclitaxel, and gemcitabine. Of the 72 patients, $26 \%$ received radiotherapy for locoregional disease control. No operative mortality or major morbidity related to treatment occurred. All the adverse effects of chemotherapy and radiotherapy were manageable.

The treatment of patients with malignant tumors of the foot and ankle is summarized in Table 3.

\section{Outcome}

The median follow-up period for the patients with malignant tumors of the foot and ankle was 27 (range 3 to 110) months. The median disease-free interval was 8 (range 0 to 107) months. Most patients had no clinical or radiologic evidence of disease recurrence at the moment. Four patients developed metastases after initial treatment and died of disease.

The 9 -year overall and disease-free survival rate was $65 \%$ and $40 \%$, respectively. The outcome of the patients with malignant tumors of the foot and ankle is summarized in Table 4 and Figs. 1 and 2.

\section{Soft Tissue Tumors}

Of the 63 patients with soft tissue tumors, 37 (57\%) were female and 27 (43\%) were male. Their age ranged from 16 to 76 (median 53 ) years. The median follow-up was 53 (range 6 to 119) months. Of the 63 soft tissue tumors, 48 (76\%) were benign and 15 (24\%) were malignant; 57 (90\%) were located in the foot and $6(10 \%)$ in the ankle. According to the regions of the foot, 24 tumors were located in the forefoot, 32 in the midfoot, and 1 in the hindfoot. The most frequent histologic diagnoses were GCT in 8 (13\%), angiomyoma in 7 (11\%), lipoma in 7 (11\%), schwannoma in $5(8 \%)$, and synoviosarcoma in $5(8 \%)$. The characteristics of the patients with soft tissue tumors are summarized in Table 5 and Fig. 3.

\section{Table 4}

Outcome of patients with malignant tumors of the foot and ankle ( $\mathrm{n}=16$ tumors in 16 patients)

\begin{tabular}{ll}
\hline Variable & Value \\
\hline Follow-up (mo) & 27 \\
Median & $3-110$ \\
Range & \\
Disease-free interval (mo) & 8 \\
Median & $0-107$ \\
Range & \\
Patient status & $8(50 \%)$ \\
CDF & $3(19 \%)$ \\
NED & $1(6 \%)$ \\
AWD & $4(25 \%)$ \\
DOD &
\end{tabular}

Abbreviations: AWD, alive with disease; CDF, continuously disease free; DOD, dead of disease; NED, no evidence of disease.

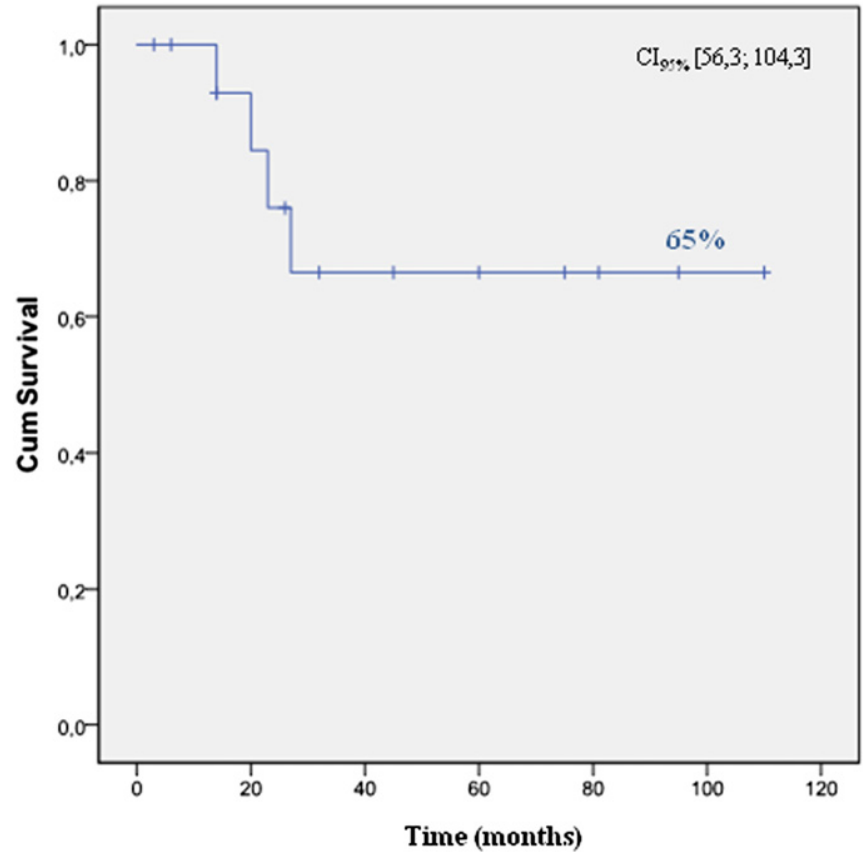

Fig. 1. Overall survival of patients with malignant tumors of the foot and ankle ( $n=16$ tumors in 16 patients).

\section{Bone Tumors}

Of the 9 patients with bone tumors, 3 were female and 6 were male. Their age ranged from 15 to 75 (median 42) years. The median follow-up was 29 (range 3 to 109) months. Of the 9 bone tumors, 7 were benign and 2 were malignant. The most frequent histologic diagnosis was osteocondroma (3 cases). The characteristics of the

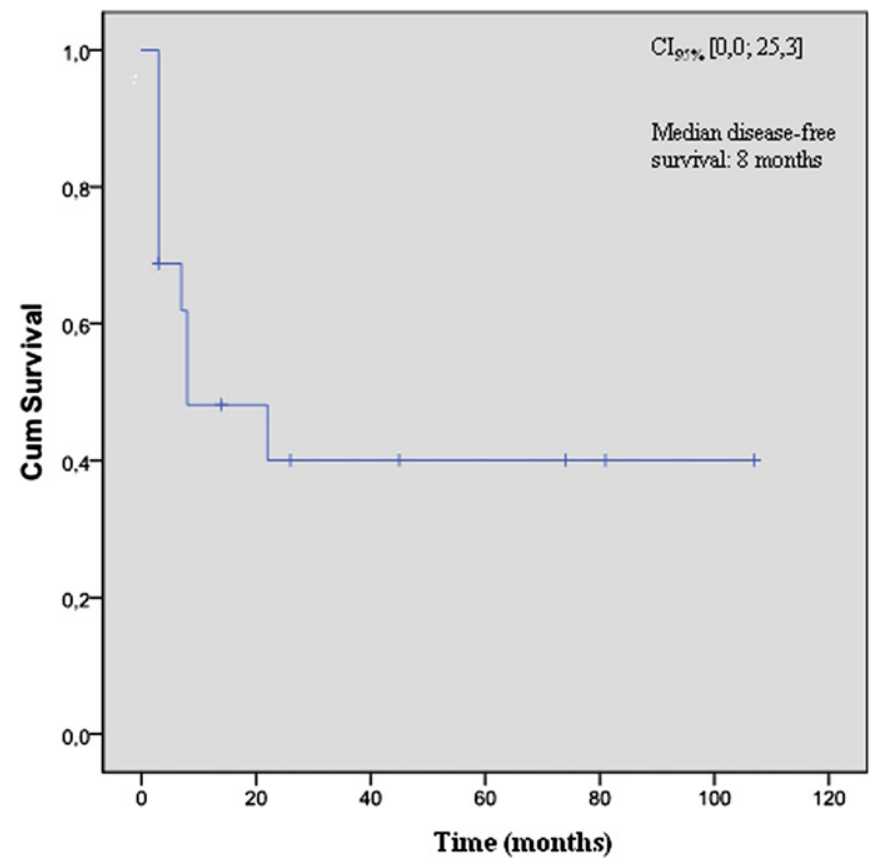

Fig. 2. Disease-free survival of patients with malignant tumors of the foot and ankle ( $\mathrm{n}=$ 16 tumors in 16 patients). 
Table 5

Characteristics of patients with soft tissue tumors of foot and ankle ( $\mathrm{n}=63$ patients)

\begin{tabular}{ll}
\hline Parameter & Value \\
\hline Age (y) & \\
Median & 53 \\
Range & $16-76$ \\
Gender & \\
Male & $27(43 \%)$ \\
Female & $37(57 \%)$ \\
Location & \\
Foot & $57(90 \%)$ \\
Forefoot & 24 \\
Midfoot & 32 \\
Hindfoot & 1 \\
Ankle & $6(10 \%)$ \\
\hline
\end{tabular}

Data presented as $\mathrm{n}(\%)$, unless otherwise noted.

patients with bone tumors are summarized in Table 6. The anatomic location of the tumors is shown in Fig. 4.

\section{Discussion}

Given that tumors of the foot and ankle are rare, the particular clinicopathologic features, therapeutic approach, and outcomes in this setting have not been extensively studied. The objective of the present study was to present the clinical outcomes of a series of 72 cases of tumors located in the foot and ankle, treated at a musculoskeletal oncology referral center, for a period of approximately 10 years.

Chou et al (12), in a 20-year retrospective review of 153 tumors of the foot and ankle, found that benign lesions and soft tissue tumors were dominant, just as was observed in our series. Moreover, both studies revealed a slight female predominance. However, the median age was 30 years in the series by Chou et al (12), but in our review was significantly older ( 52 years). However, that might be because our center does not admit pediatric patients. In relationship to the anatomic location, the foot tumors represented $86 \%$ of our sample, a significantly greater percentage than that (66\%) observed in the study
Table 6

Characteristics of patients with bone tumors of foot and ankle ( $\mathrm{n}=9$ tumors in 9 patients)

\begin{tabular}{lc}
\hline Parameter & Value \\
\hline Age $(\mathrm{y})$ & 42 \\
Median & $15-75$ \\
Range & \\
Gender (n) & 6 \\
Male & 3 \\
Female & \\
Histologic diagnosis (n) & \\
Benign & 3 \\
Giant cell tumor & 3 \\
Osteocondroma & 1 \\
Enchondroma & \\
Malignant & 1 \\
Osteosarcoma & 1 \\
Fusocellular sarcoma & \\
\hline
\end{tabular}

by Chou et al (12). In both studies, GCT was the most frequent histologic type in the benign, soft tissue, and bone subgroups, and synoviosarcoma was the most frequent malignant tumor. The median followup period was longer in our study, which could be explained by the greater percentage of benign tumors. Murari et al (6) published a series of 255 patients with foot tumors, in which $84 \%$ of the cases were benign. The most frequent benign tumor was also GCT and chondrosarcoma was the most frequent histologic type of malignant tumor.

Ozger et al (13) reported 16 cases of malignant tumors of the foot and ankle from 1989 to 1998. They found male predominance, a median age of 33 years, a more frequent tumor location in the foot (75\%), and a soft tissue tumor rate of $81 \%$. These results were quite similar to ours, except for the older median age in our study. In both studies, the most frequent histologic type was synoviosarcoma. In relation to multimodality treatment, the review by Ozger et al (13) showed that $88 \%$ underwent limb salvage surgery, in most patients, the margins were wide, $81 \%$ received chemotherapy, and $69 \%$ received radiotherapy. In our study, more patients underwent amputation (44\%), in most cases, wide or radical margins were obtained, and fewer patients received chemotherapy (62\%) and radiotherapy (26\%). In

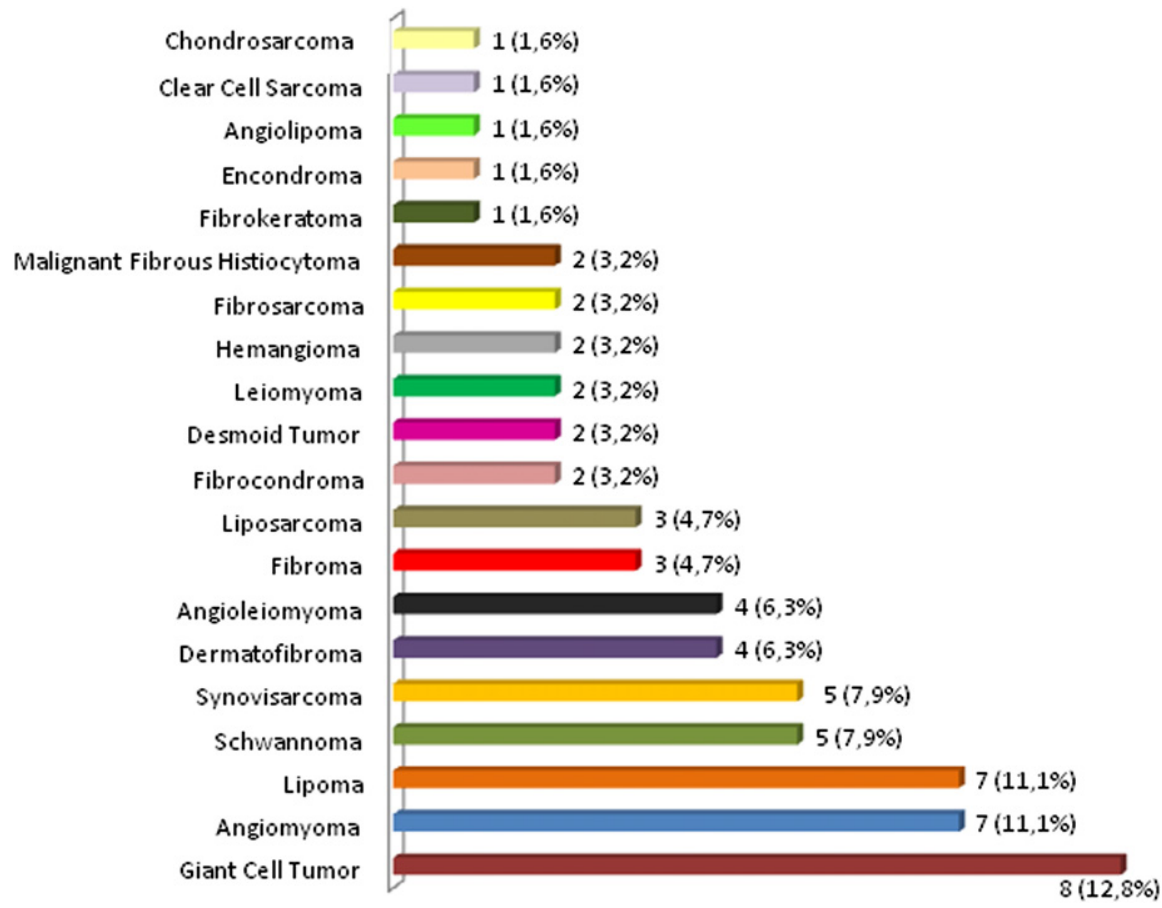

Fig. 3. Histologic diagnoses of soft tissue tumors of the foot and ankle ( $\mathrm{N}=63$ tumors in 63 patients). 


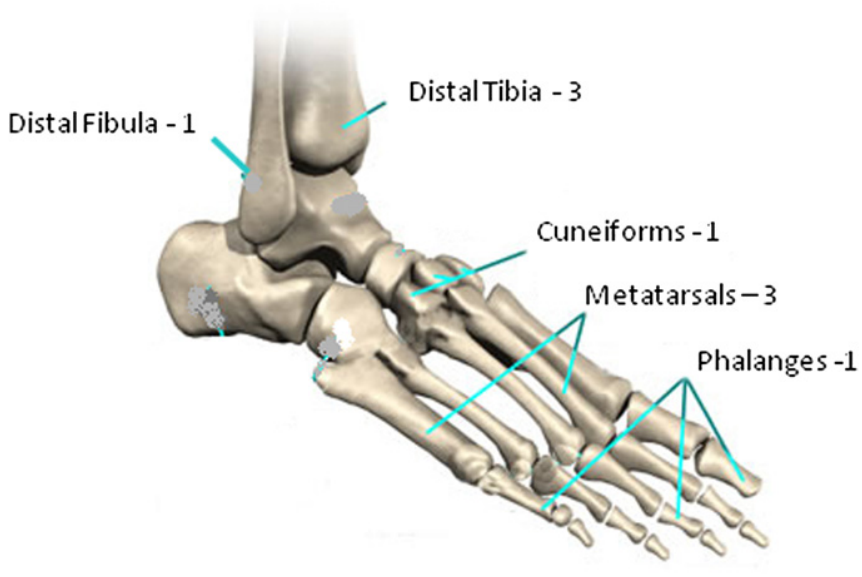

Fig. 4. Anatomic location of bone tumors of the foot and ankle.

relationship to the outcome in both series, our results showed greater survival rates, despite a significantly lower disease-free interval. This was because our institution is a referral center receiving, from other hospitals, some patients who have already undergone surgical resection with marginal margins, which results in the likelihood of local recurrence within a short period. However, our aggressive multimodality therapeutic approach, once disease recurrence has developed, is justified by the better survival rates of our patients.

The most frequent histologic type in the benign, soft tissue, and bone subgroups of our series was GCT. Soft tissue GCT, first described by Salm and Sissons (14) in 1972, is a rare neoplasm located in both superficial and deep soft tissue. It commonly involves the upper and lower extremities. The differential diagnosis should include dermatofibroma, atypical fibroxanthomas, plexiform fibrohistiocytic tumor, giant cell malignant fibrous histocytoma, osteoclast-like giant cell-rich leiomyosarcoma, extraskeletal osteosarcoma (15), nodular fasciitis with giant cells, and epithelioid sarcoma. Most cases of GCT of the soft tissue follow a benign clinical course but can be locally aggressive and recur locally. Although metastases are infrequent, cases have been reported of metastases to the lungs $(16,17)$ and parotid glands $(18)$. Our series included 8 cases of soft tissue GCT, all located in the foot. The surgery type for most of these patients was resection of the lesion. No local recurrence or metastases developed. GCT of the bone was first recognized in 1818 (19), but it was not until 1940 that it was formally distinguished from other tumors of the bone, such as aneurysmal bone cyst, chondroblastoma, and nonossifying fibroma (20). GCT of the bone is a relatively rare, benign, but locally aggressive, osteolytic skeletal neoplasm of young adults. It accounts for approximately $3 \%$ to $5 \%$ of all primary bone tumors and $15 \%$ to $20 \%$ of all benign bone tumors $(21,22)$. Most cases are solitary lesions; multicentric GCT of the bone accounts for less than $1 \%$ of the total reported cases (23). The most commonly affected sites are the epiphyses of the long bones. In about $2 \%$ to $3 \%$ of cases, distant metastases occur, most often to the lungs, but the outcome of these "benign implants" is favorable. Rarely, GCT of the bone undergoes true malignant transformation (24). In our study, as described in most reported cases, the 3 cases of bone GCT were solitary lesions located in the distal tibia and fibula with no local recurrence or metastatic disease.

The most common primary soft tissue malignant tumor in the foot and ankle is synoviosarcoma (25). Synovial sarcoma can be histopathologically divided into biphasic, monophasic fibrous, monophasic epithelial, and poorly differentiated types. In cases of the biphasic type, both epithelial and spindle cells are present; therefore, the diagnosis is relatively easy. However, in cases of the monophasic type, which has homogeneous patterns of spindle cells, immunohistochemical staining is needed to distinguish this tumor from other spindle cell-type tumors such as fibrosarcoma, hemangiopericytoma, leiomyosarcoma, and spindle cell carcinoma (26). Synoviosarcoma often arises deep in the soft tissue near a joint in the extremity, and the peak incidence is in the second to fifth decades (25). Our results were similar to those previously reported, showing that synoviosarcoma was also the most frequent histologic type of malignant tumors. All 5 cases observed were located in the foot. The mean patient age was 37 years. Only 1 patient who died of disease. The other patients have been either continuously disease free after a complete response to initial treatment or without evidence of disease, despite local recurrence and metastases in the past.

In relation to the limitations of the present study, the retrospective nature of the study is an important limitation because of the variability of some data registered in the clinical records. Also, patients with incomplete records had to be excluded. Because the selection of the cases was based on the informatic database of pathology department, tumors usually treated by destruction of the lesion with thermal ablation, such as osteoid osteoma, were not included in the present study.

In conclusion, tumors of the foot and ankle are rare and are associated with a peculiar clinical presentation, histologic diagnoses, surgical and medical approach, and patient outcome. The adequate diagnosis and treatment of foot and ankle tumors has a significant effect on the patient's functional outcome. In our series of 72 patients, the vast majority of the tumors were located in the foot. Benign tumors were dominant, outnumbering malignant tumors by more than 3 to 1 . The diversity of histologic benign types was evident, with GCT, angiomyoma, and lipoma the most frequent. Two cases were recurrent benign tumor: angiolipoma and desmoid tumor. In the malignant tumors, there was a clear male predominance, the median age was 45 years, and the most frequent tumor was synoviosarcoma. The peculiar anatomic compartments of the foot and ankle are favorable to rapid spread of malignancies arising in this location; therefore, aggressive surgical intervention is frequently required. Multimodal treatment is often necessary in these cases. The 9-year overall and disease-free survival rate was 65\% and $40 \%$, respectively. Larger scale studies of patients with tumors of the foot and ankle are needed to understand this rare subgroup of neoplasms.

\section{References}

1. Biscaglia R, Gasbarrini A, Bohling T. Osteosarcoma of the bones of the foot-an easily misdiagnosed malignant tumor. Mayo Clin 73:842-847, 1998.

2. Chou LB, Malawer MM. Analysis of surgical treatment of 33 foot and ankle tumors. Foot Ankle Int 15:175-181, 1994.

3. Gray RJ, Pockaj BA, Vega ML. Diagnosis and treatment of malignant melanoma of the foot. Foot Ankle Int 27:696-705, 2006.

4. Hattrup SJ, Amadio PC, Sim FH, Lombardi RM. Metastatic tumors of the foot and ankle. Foot Ankle 8:243-247, 1988.

5. Kirby EJ, Shereff MJ, Lewis MM. Soft-tissue tumors and tumor-like lesions of the foot-an analysis of eighty-three cases. J Bone Joint Surg 71-A:621-626, 1989.

6. Murari TM, Callanghan JJ, Berrey BH Jr, Sweet DE. Primary benign and malignant osseous neoplasms of the foot. Foot Ankle 10:68-80, 1989.

7. Seale KS, Lange TA, Monson D, Hackbarth DA. Soft tissue tumors of the foot and ankle. Foot Ankle 9:19-27, 1988.

8. Sundberg SB, Carlson WO, Johnson KA. Metastatic lesions of the foot and ankle. Foot Ankle 3:167-169, 1982.

9. Dahlin DC, Unni KK. Bone Tumors: General Aspects and Data on 8542 Cases, 4th ed, pp 149-173, 218-226, 307-315, Charles C. Thomas, Springfield, Illinois, 1986.

10. Enneking WF. A system of staging musculoskeletal neoplasms. Clin Orthop Relat Res 204:9-24, 1986.

11. Edge SB, Byrd DR, Compton CC. AJCC Cancer Staging Manual, 7th ed, p 291, Springer, New York, 2010.

12. Chou LB, Ho YY, Malawer MM. Tumors of the foot and ankle: experience with 153 cases. Foot Ankle Int 30:836-841, 2009.

13. Ozger H, Eralp L, Türker M, Basarn M. Surgical treatment of malignant tumors of the foot and ankle. Int J Clin Oncol 10:127-132, 2005.

14. Salm R, Sissons HA. Giant-cell tumors of soft tissues. J Pathol 107:27-39, 1972. 
15. Hoang MP, Rogers BB, Albores-Saavedra J. Giant cell tumor of the skin: a morphologic and immunohistochemical study of five cases. Ann Diagn Pathol 6:288-293, 2002.

16. Guo H, Garcia RA, Perle MA, Amodio J, Greco MA. Giant cell tumor of soft tissue with pulmonary metastases: pathologic and cytogenetic study. Pediatric Dev Pathol 8:718-724, 2005.

17. Oliveira AM, Dei Tos AP, Fletcher CD, Nascimento AG. Primary giant cell tumor of soft tissues: a study of 22 cases. Am J Surg Pathol 24:248-256, 2000.

18. Grabellus F, von Winterfeld F, Sheu SY, Metz KA, Jahnke K, Schmid KW. Unusual aggressive course of a giant cell tumor of soft tissue during immunosuppressive therapy. Virchows Arch 448:847-851, 2006.

19. Cooper AS, Travers B. Surgical Essays, Cox, Longman, London, 1818.

20. Jaffe HL, Portis RB. Giant cell tumor of bone-its pathologic appearance, grading, supposed variants and treatment. Arch Pathol 30:993-1031, 1940

21. Larsson SE, Lorentzon R, Boquist L. Giant-cell tumor of bone-a demographic, clinical and histopathological study of all cases recorded in the Swedish Cancer
Registry for the years 1958 through 1968. J Bone Joint Surg Am 57:167-173, 1975.

22. Baena-Ocampo Ldel C, Ramirez-Perez E, Linares-Gonzalez LM, DelgadoChavez R. Epidemiology of bone tumors in Mexico City: retrospective clinicopathologic study of 566 patients at a referral institution. Ann Diagn Pathol 13:16-21, 2009.

23. Hoch B, Inwards C, Sundaram M, Rosenberg AE. Multicentric giant cell tumor of bone-clinicopathologic analysis of thirty cases. J Bone Joint Surg Am 88:19982008, 2006.

24. Osaka S, Toriyama M, Taira K. Analysis of giant cell tumor of bone with pulmonary metastases. Clin Orthop Relat Res 335:253-261, 1997.

25. Scully SP, Temple HT, Harrelson JM. Synovial sarcoma of the foot and ankle. Clin Orthop 364:220-226, 1999.

26. Hosono T, Hironaka M, Kobayashi A. Primary pulmonary synovial sarcoma confirmed by molecular detection of SYT-SSX1 fusion gene transcripts: a case report and review of the literature. J Clin Oncol 35:274-279, 2005. 